\title{
Do international classes pay off? A cost-benefit analysis of the internationalisation of higher education in Flanders
}

\author{
Kristof De Witte ${ }^{1,2}$ (D) Mara Soncin ${ }^{1,3}$ (D)
}

Accepted: 2 July 2021 / Published online: 23 August 2021

(C) The Author(s) 2021

\begin{abstract}
Internationalisation is a major trend in higher education worldwide. Yet, little evidence is given on the net impact of international students on national economies. This study addresses this gap by estimating the benefits against the costs driven by international students in Belgium and its Flemish region in particular. Using a unique combination of various sources of micro-data, the results show net positive benefits that exceed costs by a factor ranging between 2.4 (lower bound) and 3.1 (upper bound) times. The results vary highly with the level of education, as the ratio is the lowest for doctoral students (1.2-1.6) and highest for master students (5.1-6.3). The effect is mainly driven by a high stay rate of international students, who are likely to work in the country after graduation. When considering indirect effects, our results show that there are no significant peer effects due to the presence of international students in the classroom.
\end{abstract}

Keywords Higher education - Internationalisation - Cost-benefit analysis · Student mobility · International students

JEL classification I21 $\cdot$ I23

\section{Introduction}

The number of students moving to a different country with the purpose of studying has grown steadily and represents a significant proportion of the student body in a number of

Mara Soncin

mara.soncin@polimi.it

1 Leuven Economics of Education Research, University of Leuven (KU Leuven), Leuven, Belgium

2 UNU-Merit, Maastricht University, Maastricht, The Netherlands

3 School of Management, Politecnico di Milano, Via Raffaele Lambruschini 4, 20156 Milan, Italy 
countries (Knight, 2013). The European Economic Area (EEA) attracts almost half (as estimated approximately $45 \%$ in 2017) of the entire number of international students (OECD, 2019a). However, the increasing pressure on education budgets and the use of migration targets that include international students results in increased awareness of the costs of internationalisation. ${ }^{1}$ Providing empirical evidence on the net effects of internationalisation has become an urgent matter for several countries (Münch \& Hoch, 2013; Migration Advisory Committee (MAC), 2018; Inspectie van het Onderwijs, 2019). However, previous research focused on the empirical application, while the state-of-the-art would benefit from an extensive theoretical framework and methodological details on both the direct economic impact and the indirect (i.e. externally induced, often neglected) effects of internationalisation (Throsby, 1991, 1998; CPB, 2012).

This paper contributes to this debate by using a unique combination of micro-administrative data and survey data as well as regional expenditures in the Flemish context. The methodology relies on a composite framework, by which the benefits and costs associated with public spending, social expenditure and consumption of goods are assessed, in addition to the induced effects such as student-related tourism. Moreover, the long-term impact of internationalisation is examined by building a proxy for the estimation of international students' stay rate after graduation and their subsequent contribution to the national economy. The heterogeneity of results by students' nationality, level of education attained and field of study is explored. Furthermore, the indirect effects of the presence of international students in the classroom are analysed by estimating the peer effect that internationalisation may drive. This combination of detailed data and methodology on the direct benefits and costs of international students and on the measurement of the (indirect) peer effect induced by internationalisation is the main empirical contribution of the paper.

This paper focuses on Belgium in general, and its Dutch-speaking Flemish region in particular. The reasons are threefold. The primary reason is that the Flemish higher education system is highly international, such that our estimates can be considered as upper bounds for the impact of internationalisation in other countries. About $12 \%$ of the entire student population has an international background in 2016, and their share increased by 37\% from 2013 to 2016, despite a reduction in 2017 (OECD, 2018a, 2019a). Second, the upper bound estimates are further reinforced as Belgium is a net receiving country. For each Belgian student studying abroad, around four international students select the country for their studies (OECD, 2018a). Hence, the possibility of a brain drain at the national level is highly unlikely, while the point of assessing the impact of incoming students - on whom this study focuses - is particularly urgent. Third, using the Belgian case, we can exploit micro-data from various sources such that a more comprehensive picture can arise. Given these premises, the results of the paper at hand have significant policy implications for other national and supranational authorities.

The article is organised as follows: the "Related literature" section provides a review of the relevant literature, while the "Theoretical framework" section presents a theoretical framework to study internationalisation. The "Data and methods" section explains the data sources and methodology used, while the next section describes the results obtained. A final section discusses and derives conclusions.

\footnotetext{
${ }^{1}$ Following earlier literature (Rumbley, 2012; OECD, 2018a, Inspectie van het Onderwijs, 2019), international students are characterised in the present paper as "those who left their country of origin and moved to another country for the purpose of studying", where the country of origin was that of secondary education
} 


\section{Related literature}

The literature on internationalisation in higher education has focused on three main pillars. First, the previous literature identifies a number of economic and cultural-related factors that drive internationalisation. This includes economic factors, such as overall economic performance and education costs, and non-economic factors such as the political stability or cultural and language proximity (e.g. González et al., 2011; Kahanec \& Králiková, 2011; Naidoo, 2007). In terms of economic features, the expenditure for tertiary education, the GDP per capita and the degree of openness of the economy have been found to be positively correlated to the share of international students (Caruso \& De Wit, 2015). Mixed evidence emerges on the role of tuition fees, as they are often considered as a proxy by students for educational quality; however, the amount of fees discourages student mobility if it passes a threshold (Naidoo, 2007). A number of social-related factors have also been found to influence the attractiveness of a country for international students, especially in terms of closer cultural and religious proximity, university reputation, language of instruction and peers' influence (e.g. OECD, 2018a; Van Mol \& Timmerman, 2014).

The second stream of research examines the stay rates of international students after graduation and links this to the stock of high-skilled workers. Weisser (2016) reports a substantial level of between-studies variability. For instance, evidence from the Netherlands reports stay rates between 29 and 94\%, while the numbers vary between 3 and $64 \%$ for the UK, with most of the variation depending on underlying data, level of education of graduate students and time horizon (Weisser, 2016). Also, PhD students are found to be more likely stayers after obtaining a degree. Kim et al. (2011) find that the percentage of doctorates staying in the USA has increased over time, from nearly $50 \%$ in the 1980 s to $66 \%$ in the 2000 s. However, as Han et al. (2015) point out, the difficulties in getting visas in the USA may discourage international students from staying, therefore affecting the overall attractiveness of the country. Felbermayr and Reczkowski (2012) match multinational data about bilateral student mobility and stock of international high-skilled migrants, finding that, in the year 2000 , the increase of tertiary-educated workers was $71 \%$ of the increase in international students, with high cross-country heterogeneity particularly between non- and Anglo-Saxon states. Additionally, scholars investigated the relationship between having an international education experience and the propensity to work abroad and found a positive correlation quantified by an increase from $2-4$ to $30 \%$ in the probability of entry into a foreign labour market (Oosterbeek \& Webbink, 2011; Wiers-Jenssen, 2008). Independently from the country of work, Van Mol et al. (2020) analyse the relationship between student mobility and graduates' wages and education-to-work transition length, using data from the Netherlands. In so doing, they show that positive labour market returns to student mobility disappear when controlling for selection into international education experience, probably due to the limited vertical mobility of the Dutch educational and labour markets.

The third stream of literature, and most connected to our research, discusses the most comprehensive way to assess costs and revenues generated by the presence of international students, by means of cost-benefit analyses at institutional or national levels (Chishti, 1984; De Villé et al., 1996; Throsby, 1991, 1998). Recently, there are quantitative contributions to this discussion by analysing the costs and benefits in national contexts such as the Netherlands (Centraal Planbureau (CPB), 2012, Inspectie van het Onderwijs, 2019), Germany (Münch \& Hoch, 2013) and the UK (London \& Partners, 2018; London Economics, 2018; Migration Advisory Committee (MAC), 2018). 


\section{Theoretical Framework}

The studies assessing the costs against the benefits of internationalisation for the hosting economy agreed on the general categorisation between direct and indirect (or external) effects. The theoretical framework on which the present study is grounded takes advantage from the previous contributions in the field moving from the general categories provided by Throsby (1998). According to the author, costs and benefits of internationalisation may be traced back to four categories: (i) resource costs borne by institutions, (ii) administrative costs borne by governments, (iii) direct economic benefits and (iv) external effects. A detailed description of dimensions related to each of the cost/benefit categories mentioned in the literature is given in Table 1. Costs that arise at the institutional level are mainly due to the programme delivery and the functioning of facilities. Their size is proxied by the level of public expenditure in tertiary education (refer to category 1.a in Table 1). Second, costs may be driven by the number of scholarships and subsidies granted to international students (1.b) and by specific student support expenditures (1.c) (e.g. admission administration). Besides, there are also public social costs due to the presence of international students in the country, mainly because of healthcare and social security (2.d).

On the other hand, direct benefits arise from private social contributions that are again related to healthcare or social security expenditures (3.e). The direct benefits also derive from tuition fees, which might vary according to the country of residence, as is the case for non-

Table 1 Theoretical framework: dimensions and indicators related to each of the cost/benefit categories

\begin{tabular}{|c|c|c|}
\hline $\begin{array}{l}\text { Reference category (adapted } \\
\text { from Throsby, 1998) }\end{array}$ & Dimension & $\begin{array}{l}\text { Expected } \\
\text { impact }\end{array}$ \\
\hline \multicolumn{3}{|l|}{ "Hard" - Direct effects } \\
\hline \multirow[t]{3}{*}{ (1) Costs borne from institutions } & a. Public spending for education & $(-)$ \\
\hline & b. Scholarships/subsidies & $(-)$ \\
\hline & c. International students support & $(-)$ \\
\hline $\begin{array}{l}\text { (2) Costs borne from } \\
\text { governments }\end{array}$ & d. Public social costs (social security; healthcare) & $(-)$ \\
\hline \multirow{4}{*}{ (3) Direct economic benefits } & e. Private social contributions (social security; healthcare) & $(+)$ \\
\hline & f. Tuition fee income & $(+)$ \\
\hline & g. Consumptions (non-tuition fee expenditure) & $(+)$ \\
\hline & h. Income from visitors & $(+)$ \\
\hline$(3)-(2)-(1)$ & $\begin{array}{l}\text { i. Long-term labour market outcomes and net contribution to } \\
\text { GDP (conditional on the probability of staying after } \\
\text { graduation) }\end{array}$ & $(+/-)$ \\
\hline \multicolumn{3}{|c|}{ grautuation) } \\
\hline \multirow[t]{9}{*}{ (4) External effects } & a. Classroom peer effect & $(+/-)$ \\
\hline & b. Cultural barriers due to a composite student population & $(-)$ \\
\hline & c. Multicultural environment & $(+)$ \\
\hline & d. Global status of domestic universities & $(+)$ \\
\hline & e. Induced investments and trade & $(+)$ \\
\hline & f. Soft diplomatic power & $(+)$ \\
\hline & g. Competition across institutions & $(+/-)$ \\
\hline & h. Displacement of domestic students & $(-)$ \\
\hline & $\begin{array}{l}\text { i. Indirect and induced effects on local economy by } \\
\text { means of economic multipliers }\end{array}$ & $(+)$ \\
\hline
\end{tabular}

Note: All the dimensions of costs and benefits are traced back to the reference categories proposed by Throsby (1998) to explain the economic impact of international students. For each of the direct and indirect effects, we report the direction of the expected impact based on the literature that mentions the dimension as a source of cost or benefit due to the presence of international students 
EEA students in Europe (3.f). Additionally, benefits come from non-tuition fee expenses, which are due to students' purchases of goods and services that generate income for the supplying industries and, hence, for the national economy (3.g). The benefits further originate from students' relatives and friends, who visit the hosting country and spend money that again affects the overall economy (3.h).

Besides, an important element of internationalisation is the long-term effects, as measured by labour market outcomes and by the contributions given and received by international students staying in the host country after graduation. Their estimation is subject to significant variation depending on the stay rate of international students and requires a dynamic approach to be estimated (Centraal Planbureau (CPB), 2012; Weisser, 2016).

Finally, the framework includes the indirect effects of internationalisation, which consist of various sources. First, there might be externalities that are driven by a peer effect in the classroom (4.a). Earlier research provided evidence on peer effects in higher education (Sacerdote, 2001; Zimmerman, 2003). The report by CPB (2012) provided a descriptive measure of the phenomenon in the Netherlands, suggesting that international students have higher educational outcomes than domestic ones. An additional indirect effect that is measured in the literature is the radial effect on the economy that is produced by international students. The report by the London Economics (2018) estimated the impact through the estimation of economic multipliers and observed a net positive effect of internationalisation (4.i). Besides this, additional indirect effects were reported in earlier studies; however, they were not measured in any way in their economic impact. The effects may have been related to the integration of different cultures that may result in cultural barriers (4.b) or, on the contrary, in a positive multicultural environment (4.c). Moreover, internationalisation leads universities to compete for a global pool of talents, fostering competition (4.d) and increasing visibility and reputation (4.g) that is expected to be beneficial especially for a restricted sample of prominent universities, which generally attracts international students for their already prestigious reputation. The presence of international students is also expected to play a positive role in attracting foreign trades and investments (4.e) and in increasing the diplomatic power (4.f) of the hosting nations, given the closer relationship with the students' countries of origin.

As a possible drawback, internationalisation may cause the displacement of domestic students (4.h). This is due to the capacity constraint of university facilities and to the possible interest of universities to enrol more international students than domestic ones, because of the higher revenues and positive expected externalities. The monetary value of these dimensions is rarely computed because of the difficulty to make them measurable. Still, it is important to consider them in a theoretical framework that analyses the overall impact of internationalisation. In fact, they indirectly affect human capital or economic dimensions that in turn generate financial effects linked to internationalisation.

\section{Data and methods}

The paper exploits various sources of administrative data to provide a comprehensive costbenefit analysis of internationalisation in higher education. In particular, it answers the following research questions: (1) From the perspective of the national economy, what are 
the monetary benefits of internationalisation in higher education? (2) What is the indirect impact of internationalisation in higher education in terms of peer effects of international students in the classroom?

To answer our first research question, we perform a cost-benefit analysis, in which the direct effects are monetised to estimate their actual value (Levin, 1987; Levin et al., 2017). All data refer to the latest year for which complete data are available, which corresponds to the academic year 2015/2016 (further denoted by 2016). However, when data for 2016 were not available, the data from the most recent year was utilised and the costs were adjusted accordingly to 2016 prices by making use of the harmonised consumer price index (similar to Schreyer \& Koechlin, 2002). The present paper also estimates the peer effects induced by the presence of international students in the classroom. A detailed description of the data and methodology is provided below and complemented by the Online Supplementary Appendixes $\mathrm{A}$ and $\mathrm{B}$.

To assess the number of international students, we rely on data provided by the Flemish Ministry of Education. This allows observing the precise number of international students enrolled in Flemish education in 2016 (equal to 21,898 students) as well as the level of education they are enrolled in. This further element makes it possible to observe students' distribution across educational levels. Moving from this reference information, the following paragraphs describe the data sources and the formulas used for computing each component of our theoretical framework: the costs and benefits during education, the costs and benefits after graduation and the evaluation of the indirect peer effects.

\section{Costs and benefits during education}

Making reference to our theoretical framework, we first compute the costs related to public spending for education by combining the yearly expenditure per tertiary student (OECD, 2018b) with the number of international students and the average duration of studies. The regular duration of study is considered for bachelor and $\mathrm{PhD}$ students (i.e., 3 and 4 years, respectively), while for master students we use as a proxy micro-data from KU Leuven, given the possible variability (formally, either 1 or 2 years) in the duration of master programmes. Despite potential selection effects of students in a specific institution, we consider the distribution observed in KU Leuven as a proxy for Flanders, given that this university counts nearly half of the total number of international students. The observed duration of studies for master students amounts to $33 \%$ of the students completing the study programme in one year; $47 \%$ takes two years to complete; $14 \%$ needs three years, while $6 \%$ takes four years or more. The formula used for the calculations of the public spending for education is the following:

$$
\begin{aligned}
\text { Total costs } & =\sum_{t}^{n}[\mathrm{~N}(\text { tertiary students }) \times \text { expenditure }(\text { tertiary education }) \\
& +\mathrm{N}(\mathrm{PhD}) \times \text { expenditure }(\mathrm{PhD})]_{t} \times(1+i)^{t-1}
\end{aligned}
$$

where $n$ represents the duration of studies as presented above, while the factor $(1+i)^{t-1}$ allows considering all the values in 2016 prices adjusted for an inflation rate $i$ (similarly to Thompson, 2009). This permits accounting for the fact that the students who graduated in 2016 enrolled in the educational system $t$ years before. The inflation rates are those referred to the period 20122015 as reported by OECD $(2018 b)$. 
As a dimension of costs, public social costs have been proxied considering public spending for social security services and healthcare. Data have been retrieved by OECD (2018b, 2019b) and have been stratified by age in order to avoid under or over allocation. The mathematical formula can be expressed as follows:

$$
\begin{aligned}
\text { Total costs } & =\sum_{t}^{n}[\mathrm{~N}(\text { international student }) \times \text { expenditure }(\text { healthcare }) \\
& +\mathrm{N}(\text { international student }) \times \text { expenditure }(\text { social security })]_{t} \times(1+i)^{t-1}
\end{aligned}
$$

Concerning benefits, private social contributions are firstly considered and computed by using data provided by OECD (2018b) through a formula that can be expressed as follows:

$$
\text { Total benefits }=\sum_{t}^{n}[\mathrm{~N}(\text { international student }) \times \text { expenditure }(\text { social })]_{t} \times(1+i)^{t-1}
$$

As the second source of economic benefits, tuition fee incomes are considered for the academic year 2016. In detail, we consider separate fees for EEA and non-EEA students, as well as for bachelor/master and $\mathrm{PhD}$ students (who pay a fee only in the first and last year of attendance, thus for half of the four-year cycle). This can be specified through the following calculation:

$$
\begin{aligned}
\text { Total benefits } & =\sum_{t}^{n}\left[\mathrm{~N}(\text { EEA }) \times \text { fee }(\text { EEA })+\mathrm{N}(\mathrm{PhD}) \times \frac{\text { fee }(\mathrm{PhD})}{2}\right. \\
& \left.+\sum_{k}^{m} \mathrm{~N}(\text { non EEA })_{k} \times \text { fee }(\text { non EEA })_{k}\right]_{t} \times(1+i)^{t-1}
\end{aligned}
$$

where, in addition to the previous subscripts, we add the summation of the fees for non-EEA students (decided by the single university) in each of the $k$ th universities in Flanders, where $m$ represents the total number of universities.

To estimate the benefits generated by "good consumption", we used data from the Household Budget Survey (HBS), a representative survey taken every two years by the Belgian Statistical Office (StatBel) that is filled out by Flemish families about their purchases of goods and services. In the 2014 wave, 6131 households completed the survey, reporting monthly expenditures for food and beverages, clothes, maintenance and repair of personal transport, facilities, furniture, communication devices, culture and leisure, education and private healthcare. The survey data is used to compute the expenditure for goods and services, as well as to compute the non-fee income generated by international students. The computation of the total costs can be expressed as:

$$
\text { Total benefits }=\sum_{t}^{n}[\mathrm{~N}(\text { international student }) \times \text { expenditure }(\text { consumption })]_{t} \times(1+i)^{t-1}
$$

To estimate the income from students' visitors, we started from the number of tourists that came to Flemish art cities to "visit relatives and friends" and we traced the number of visitors related to international students by computing a ratio to indicate the proportion of international students by nationality over the overall number of foreign people from that country (OECD, 2018a). Having the information about the average expenditure and length of stay for each of the main nationalities visiting Flanders (Toerisme Vlaanderen, 2017, 2018), we could analytically compute the total benefits through the following formula:

$$
\begin{aligned}
\text { Total benefits }= & \sum_{t}^{n}\left[\sum_{y}^{p}[\text { Ratio } \times \mathrm{N}(\text { visitors }) * \text { Length } * \text { Expenditure } / \text { day }]_{y}\right. \\
& \times \text { Proportion }(\text { international students })]_{t} \times(1+i)^{t-1}
\end{aligned}
$$


where the subscript $y$ refers to each country considered in the analysis (i.e. the main EU countries separately and the average for the remaining ones).

\section{Costs and benefits after graduation}

The first step to compute the long-term benefits and costs related to international students is to build a proxy of student retention after graduation. Hence, micro-level data is used from the Flemish Government Social Security Data to estimate the student stay rate. The data link education outcomes of all individuals who graduated (or dropped out) from tertiary education in 2011 to labour market outcomes in the consequent ten quarters after leaving tertiary education. Unfortunately, it is not possible to link these data with the specific information on international students provided by the Flemish Ministry of Education. For this reason, we define a proxy to identify international students and measure their stay rate. Overall, 53,305 individuals are observed in the Social Security dataset, which correspond to all students irrespective of the university (or university college) attended. As also citizenship is recorded, an indicator is constructed to measure the presence of international students in the Flemish labour market. Also, to disentangle the population of people coming with the purpose of studying from those already living in the country but being born abroad, the subpopulation of foreign graduate students is considered who were not granted a scholarship during their studies, as students are only entitled to scholarships if they live or work for a substantial period of time in the country. ${ }^{2}$ This way, 2027 international graduate students are observed, who make up $4.6 \%$ of the sample. Linking the degree of the student to the Social Security data, the stay rate is measured by examining whether the student appears in the Social Security data (either as employed or unemployed) as this means that they remained in the country after graduation.

Moreover, given that the decision to stay in a country is a dynamic phenomenon, but no data on the length of stay of international students in Flanders is currently available, the likelihood of staying over time has been proxied by using the DIOC database ${ }^{3}$ (Database on Immigrants in OECD Countries, OECD, 2013a). The database enables the creation of a proxy for the length of stay of international students, assuming that the average length of stay of highly educated immigrants in the past reflects the behaviours of graduate students in the future.

Moreover, we consider aggregate OECD data to account for drop-out rate in tertiary education, social expenditure and unemployment rate (OECD, 2013a, 2013b, 2018a, 2018b, $2019 b$ ). Data related to students' earnings after graduation are based on projections valid for the entire Flemish population and presented in the salary calculator of the website Vacature. com. ${ }^{4}$

After this preliminary data collection, we compute the long-term benefits as represented by good expenditures, private social contributions, taxation on gross salaries (average taxation amounts to 53.9\%; OECD, 2018a) and employer contribution (average contribution amounts to $32.8 \%$; OECD, 2019b). The underlying reason for the increase in salaries is due to work experience (i.e. seniority), while other values are held constant and discounted to the average

\footnotetext{
${ }^{2}$ Ignoring this assumption in the data delivers robust findings, as the full number of foreign citizens amounts to 2209 people. Although the stay rate is with $55.5 \%$ slightly higher without the assumption on scholarships (instead of $52.8 \%$ ), our main findings hold.

${ }^{3}$ http://www.oecd.org/els/mig/dioc.htm (Accessed July 2019)

${ }^{4}$ https://www.jobat.be/en/salary-calculator (Accessed November 2019)
} 
inflation rate between 2010 and 2017 (1.8\%; OECD, 2018b). Long-term costs are made by social expenditures incurred by the government, which are composed of (i) income support to the working-age population; (ii) family services (since five years after graduation) and (iii) pensions (since forty years after graduation). These values are kept constant over time and discounted to the average inflation rate of $1.8 \%$ (OECD, 2018b), in order to estimate their present value. The number of international graduates working in the national job market is highly dependent on the drop-out rate during tertiary education, which is equal to $24 \%$ in Flanders. The drop-out rate provided by OECD has been triangulated using data from KU Leuven, showing that drop-out among international students is slightly lower, i.e. 21-22\%. Nevertheless, given the uncertainty in the data and the importance of graduation for the findings, we use the drop-out rate to provide upper and lower bound estimations. In particular, the upper bound corresponds to the best-case scenario in which all international students graduate, while the lower bound assumes a drop-out rate of $24 \%$ among the international students. Finally, we compute the net present value (NPV) which measures the difference between the discounted value of benefits and costs as follows:

$$
N P V=\sum_{t=1}^{n} \frac{B_{t}}{(1+i)^{t-1}}-\sum_{t=1}^{n} \frac{C_{t}}{(1+i)^{t-1}}
$$

where $B_{t}$ and $C_{t}$ are, respectively, the benefits and the costs; $t$ refers to the reference year, ranging from 1 to $n$; and $\mathrm{i}$ is the discount rate, which is assumed to be equal to the inflation rate.

The NPV has been used also as an economic measure to estimate the overall economic impact of internationalisation, by considering both the costs and benefits arising during education and those arising after graduation. In addition, the benefit-cost (BC) ratio, where the present value of benefits is divided by that of the costs, has been computed.

\section{Evaluation of the indirect peer effects}

To evaluate the second research question (i.e. the peer effects induced by the presence of international students in the classroom), the population of students that are enrolled at master and advanced master level (master after master) at the KU Leuven is considered (cohorts 2007-2017), as further detailed in the Online Supplementary Appendix B.

Starting from an education production function (EPF), the peer effects are estimated by the following regression model:

$$
y_{i j t}=\theta_{0}+\theta_{1} X_{i j t}^{1}+\theta_{2} X_{j t}^{2}+\theta_{3} P_{-i j t}+\varphi_{j}+\rho_{t}+\varepsilon_{i j t}
$$

where $y_{i j t}$ refers to a number of educational attainment measures for the student $i$ within the programme $j$ in the cohort $t$. Output measures refer to (i) time to graduation (in years); (ii) grade point average (GPA); (iii) exam success measured by courses succeeded by the student over the number of courses in the study plan (hence ranging between 0 and 1); and (iv) student drop-out (a dummy identifying students who never got a degree). The controls are captured by $X_{i j t}^{1}$, which specifically refers to students' level characteristics (e.g. gender, scholarship, age); $X_{j t}^{2}$ refers to a set of controls at the programme level (e.g. two-year programme, English programme); $P_{-i j t}$ is a measure of the peer effect which is equivalent to the proportion of international students within programme without including the student $i ; \varphi_{j}$ indicates 
programme fixed effects to capture observed and unobserved differences at the programme level and $\rho_{t}$ controls for time fixed effects.

\section{Results}

The direct costs and benefits of internationalisation in higher education are summarised in Table 2. First, we compute all the costs and benefits related to international students during their studies, and then we consider the long-term benefits and costs based on students' stay rate. Following the structure of the theoretical framework, dimensions of costs are composed of public spending for international students in higher education and of welfare costs as social security and healthcare for international students. Educational expenditure per student in tertiary education, as provided by OECD (2018b), is multiplied by the 21,898 international students in Flanders in 2016, as given by the Flemish Ministry of Education. Of them, 31.5\% are doctoral students, while the remaining students are almost evenly distributed between bachelor and master level (34.7\% and 33.8\%, respectively). Moreover, yearly expenditure is multiplied by the average duration of studies as specified in the "Costs and benefits during education" section. As the yearly public expenditure per student amounts to nearly $€ 17,700^{5}$ per student in tertiary education and to $€ 45,000$ for doctoral students (that is the value of the doctoral scholarship) ${ }^{6}$, a total amount of around $€ 1902$ million is derived for educational provision to international students (see Online Supplementary Appendix A.1.a).

The second dimension of costs consists of the amount of money allocated for tertiary education scholarships and subsidies (see Online Supplementary Appendix A.1.b). The scholarships and subsidies are ignored as international students are typically not entitled to them in Flanders (although there are some very specific scholarship programmes like the one provided to the top $2 \%$ performers of non-EER students, for most scholarships, students have to live or work in the country for a substantial period of time before being eligible for a scholarship).

The third dimension in the theoretical framework considers the budget allocation within HE institutions to provide support for international students (see Online Supplementary Appendix A.1.c). Institutional support for international students is ignored as there is a lack of reliable data about costs borne by HE institutions for international activities. Most institutional support for international students is spread between the central level in universities and the different faculties, which makes it intricate to measure the costs in a reliable way. Hence, the costs may be underestimated in this respect. However, in the Flemish context, financial transfers by the government account for the proportion of international students enrolled; thus, these costs are partially included in the expenditure per student previously specified.

As the fourth dimension of costs, the amount of money incurred for the provision of social services is computed, in terms of social security and healthcare for international students (a detailed discussion on the measurement of these costs is provided in Online Supplementary Appendix A.1.d). For the estimation of healthcare costs, the health costs for young people are proxied assuming that public costs for this category of social services are strongly

\footnotetext{
${ }^{5}$ The variable is defined as "Spending includes instruction and ancillary services for students and families provided through educational institutions." (OECD, 2019a)

${ }^{6}$ We acknowledge the fact that not all the doctoral students receive a scholarship. Hence, our estimates can be considered as upper bounds in this respect
} 
Table 2 Estimation of the direct costs and benefits of internationalisation

Direct effects

1. Costs

a. Public spending

$€ 1,902,195,573$

b. Social costs (social security; healthcare)

$€ 213,345,385$

$€ 2,115,540,958$
2. Benefits

a. Private social security

$€ 47,873,210$

b. Student fees

$€ 57,445,418$

c. Consumptions (accommodation costs, subsistence,

direct course costs)

$€ 630,560,695$

d. Income from visitors

$€ 139,421,564$

e. Taxation and contribution to GDP (subsequent net revenues conditional on the probability of staying after graduation) net of costs

$€ 4,230,178,084$

$€ 5,566,023,795$

Total

$€ 5,105,478,971$

$€ 6,441,324,682$

Source: Authors' elaboration on OECD (2013a, 2013b, 2017, 2018a, 2018b, 2019); Flemish Government Social Security Data; HBS survey; Toerisme Vlaanderen (2017, 2018)

Note: Direct costs and benefits driven by the presence of international students in the short and long run are given. For total benefits, we compute a lower bound (in case all students got a professional bachelor degree) and an upper bound (in case all students got an academic master degree) of estimation

differentiated along the citizen's life, with elderly people and children outweighing and young adults underweighting the average. For social security costs, we consider the social expenditure for support to the working-age population that represents $7.5 \%$ of GDP per capita as given by OECD (2019b) and includes incapacity benefits, family cash benefits, unemployment benefits and other social supports in cash $^{7}$. Given that this percentage may be overallocated to international students, we apply the same reduction used for healthcare costs to calculate the cost per student. Indeed, we may assume that a similar age stratification holds for healthcare as well as for social security costs. The sum of the social security and healthcare costs makes up $€ 3283$ per student, which is multiplied by the overall number of international students and by the average duration of studies. This gives a total amount of nearly $€ 213$ million.

The second main reference category in the theoretical framework refers to the direct economic benefits. The benefits are represented by private social contributions, tuition fee income, non-tuition fee income (good expenditure) and income from visitors. Moreover, the long-term labour market outcomes and net contribution to GDP (conditional on the probability of staying after graduation) are estimated. The private social contributions made by students (e.g. due to student jobs) are approximated by OECD (2018b) as making up $1.80 \%$ of the GDP per capita, equal to $€ 737$ per person. That multiplied by the number of international students makes up an amount of nearly $€ 48$ million.

The second dimension in the benefits consists of the tuition fee income (Online Supplementary Appendix A.2.b), which varies by the level of education and student's nationality.

\footnotetext{
${ }^{7}$ Despite not being specifically related to international students, this is the best proxy available to account for any social security costs incurred for social or community services provided to students.
} 
The general tuition fee in 2016 is equal to $€ 890$ per student, with the exception of non-EEA master students, whose average tuition fee corresponds to $€ 2283$, and doctoral students, whose tuition fee is $€ 450$ only in the first and last years of attendance. Summing up the different components and multiplying by the duration of studies, a total amount of nearly $€ 57$ million tuition fees of international students is obtained.

The third dimension considers the benefits from non-fee income, which includes not only all expenditures for purchases related to food, beverages, transports, personal care, leisure activities, but also rent and private healthcare (Online Supplementary Appendix A.2.c). In the Household Budget Survey, households with and without children with a tertiary education age (18-30 years) are distinguished and the household expenditure is divided by the number of family components ${ }^{8}$. This is carried out by means of micro-data related to Flanders, ensuring a high level of accuracy despite the fact that data are not specifically related to international students. Multiplying the monthly expenditure per person in 2016 prices (€808) by the total number of international students and duration of studies, the total spending of international students on food, beverages, transport, leisure activities and personal care of $€ 630$ million is obtained.

Finally, as a fourth dimension, income generated by tourists visiting relatives or friends who study in Flanders is obtained by using data collected by the Flemish Tourism Office (more detailed discussion in Online Supplementary Appendix A.2.d), disentangling the expenditure by tourists coming to Flanders to visit relatives working in the region from those coming because of students. In total, an amount of nearly $€ 139$ million per year is obtained that is spent on visiting international students.

As the third reference category, the long-term effect induced by international students is assessed (Online Supplementary Appendix A.3). This is profoundly related to the estimation of the probability of living and working in the country after graduation. The results based on the analysis of the Flemish Government Social Security Data show a stay rate of $52.8 \%$, suggesting that more than half of international students stay in Belgium for at least a few months after graduation. This is an interesting result in itself, even though the intertemporal variation has to be considered in this decision to estimate its long-term effect. The use of the DIOC database allows building this projection, as outlined in the Online Supplementary Appendix A.3 and shown graphically in Figure 1. The resulting distribution of students is structured as follows: about half of the international students stay after graduation at least a quarter. Of the students who stay at least one-quarter, $13 \%$ of graduate students leave within one year. $45.9 \%$ of the international students stay for more than one year but less than five years. About $37.2 \%$ of the international students stay for five to ten years; $29.4 \%$ of them will stay for ten to twenty years; the final $22.3 \%$ will stay for life.

This distribution of the stay rate is the basis for the computation of future benefits and costs. In line with the general theoretical framework, we estimate the NPV to actualise the yearly difference between benefits (good expenditures, private social contributions, taxation on gross salaries and employer contribution) and costs (income support to the working-age population, family services and pensions). The results show that the long-term benefits outweigh the costs, and the net lower bound corresponds to a present value of $€ 4.2$ billion; the net upper bound constitutes a value of $€ 5.6$ billion.

\footnotetext{
${ }^{8}$ We are aware that these data are not specifically referred to international students. However, it is the best proxy available to account for good expenditure
} 


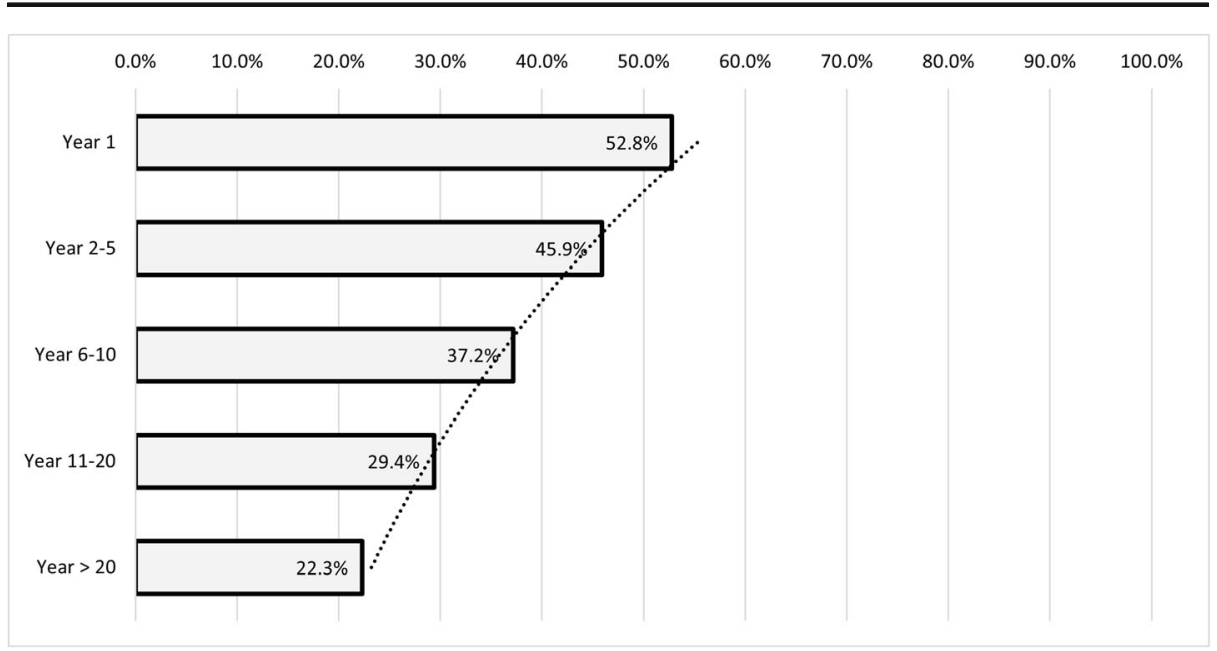

Figure 1 Estimated stay rate of international students over time in Flanders. Source: Authors' elaboration on Flemish Government Security Data and DIOC 2010/11 (OECD, 2013a). Note: The figure shows the stay rate of international students in Flanders after graduation. The more international students leave the country, the more the stay rate decreases, as it is the case over time

Comparing the estimated costs and benefits, overall, cost-benefit measures given in Table 3 report a net benefit from the presence of international students in the country of $€ 2990$ million to $€ 4326$ million euro, corresponding to $1.2 \%$ to $1.7 \%$ of GDP in Flanders. The total benefits are a factor of 2.4 to 3.1 times the total costs, with a net contribution to the national economy per student ranging between $€ 136,539$ and $€ 197,542$. Additional insights about the robustness of our findings in relation to alternative stay rates and students' length of stay are given in the Online Supplementary Appendix C.

The paper reports heterogeneous results by nationality, level of education and field of study selected by international students, as summarised in Table 4 . The highest benefit-cost ratios emerge for students coming from neighbouring countries (namely France, Germany and the Netherlands) and for those pursuing a bachelor or a master degree. Moreover, when analysing results by field of study, the benefit-cost ratio is the highest for biomedical degrees. The first result is driven by the higher stay rate for students from neighbouring countries relative to non-European students. The second result is led jointly by lower costs of education because of the shorter duration of studies for master students, and by a high stay rate for bachelor students. On the heterogeneity by nationality, given the increase in the number of students coming from extraEuropean countries (OECD, 2018a), the issue of stimulating the stay rate for this subgroup of

Table 3 Cost-benefit measures of internationalisation of higher education in Flanders

\begin{tabular}{lll}
\hline & Lower bound & Upper bound \\
\hline Overall NPV & $€ 2,989,938,014$ & $€ 4,325,783,724$ \\
Benefit-cost ratio & 2.4 & 3.1 \\
Net contribution per student & $€ 136,539$ & $€ 197,542$ \\
\hline
\end{tabular}

Note: Overall net present value (NPV) is computed by means of actualisation of future benefits and costs derived from the presence of international students, both during studies and afterwards. Benefit-cost ratio is computed as the ratio between the overall benefits and costs of internationalisation. The net contribution per student is obtained by dividing the overall NPV by the number of international students estimated in 2016 
Table 4 Analysis of heterogeneity in stay rates and benefit-cost ratios by international students' nationality and level of education attained

$\begin{array}{lll}\text { Proportion of the } & \text { Stay rate } & \text { Benefit-cost ratio }\end{array}$

Panel A: By nationality

Neighbouring countries

Other EU countries

Other Europe extra EU

Rest of the world

international student population

Panel B: By level of education

Bachelor degree $\quad 34.70 \%$

Master degree $\quad 33.80 \%$

$\begin{array}{lll}36.10 \% & 64.90 \% & 2.9-3.8 \\ 10.50 \% & 60.40 \% & 2.8-3.6 \\ 1.60 \% & 51.70 \% & 2.2-2.8 \\ 51.80 \% & 38.40 \% & 1.8-2.3 \\ 34.70 \% & & \\ 33.80 \% & 63.00 \% & 3.7-4.6 \\ 31.50 \% & 45.40 \% & 5.1-6.3 \\ & 56.60 \% & 1.2-1.6 \\ 62.50 \% & & \\ 24.50 \% & 55.90 \% & 2.5-3.2 \\ 12.50 \% & 48.10 \% & 2.3-2.9 \\ & 60.10 \% & 2.8-3.6\end{array}$

Doctoral degree $\quad 31.50 \%$

Panel C: By field of study

Humanities

STEM $24.50 \%$

Biomedical $\quad 12.50 \%$

$48.10 \%$

$2.3-2.9$

Source: Authors' elaboration on $\operatorname{OECD}$ (2013a, 2013b, 2017, 2018a, 2018b, 2019b); Flemish Government Social Security Data; HBS survey; Toerisme Vlaanderen $(2017,2018)$

Note: The proportion of international student population presents the breakdown of students across categories. The stay rate reports the proportion of students who stayed in Belgium at least one-quarter after graduation. The benefit-cost ratio is computed considering all the components of benefits and costs. The two values of the benefitcost ratio reported by nationality refer to the upper and lower bounds of estimation (the first in the case that the entire population gained a professional bachelor degree, the second in the case of academic master degree). The benefit-cost ratio reports an upper and a lower bound, depending on the fact that the computation is made net or gross the student drop-out rate

students is central and highly related to the national immigration policies. On the heterogeneity by level of education, the high benefits deriving from the presence of international master graduates should be interpreted carefully. Master graduates represent a highly skilled labour force, whose wage growth is faster than that of bachelor graduates. Though, before entering the master level, the costs for the bachelor degree might be incurred by the hosting country or by the country of origin. In the former case, the current calculation underestimates the real costs that should actually consider the costs for students' overall tertiary education. In the latter case, the competition across countries would go even further, encouraging hosting education systems to attract international students whose tertiary education was already partially fulfilled (also in terms of costs incurred) in another country. Finally, on the heterogeneity by field of study, the fact that biomedical degrees present the highest benefit-cost ratio should be interpreted in line with the cost per study program, which is usually higher for biomedical degrees than for other study fields. The lowest benefit-cost ratio is observed for STEM disciplines, whose stay rate should be increased in order to observe a growth in the net benefits. This is especially relevant in a context in which the rise of STEM graduates would be particularly beneficial for innovation and entrepreneurship (VARIO Vlaamse Adviesraad voor Innoveren \& Ondernemen, 2017, 2017).

On the peer effects estimation, our analysis does not present any statistically significant effect of the percentage of international students on their peers' attainment, except for a small negative effect on study success (measured as a number of courses succeeded over the courses booked during the last year before graduation). In particular, an additional $1 \%$ of international students are related to an average $0.7 \%$ decrease in the ratio between courses passed and booked at master level, as discussed more extensively in the Online Supplementary Appendix B. 


\section{Discussion and conclusion}

This study analyses the benefits against the costs of internationalisation in higher education, with an empirical application to Flanders, Belgium. Direct costs and benefits have been compared in the short run (i.e. during students' education) and the long run (i.e. after graduation, conditional on the probability to live and work in the host country). This study is one of the first to take full advantage of the amount of data increasingly available on the topic, offering a quantification of the impact of internationalisation on a western economy based on sound data at different levels of aggregation. Moreover, it contributes by giving clear evidence on the methodology used for the estimation of both direct and indirect effects (this latter being measured as the peer effects generated by having international students in the classroom).

Results show a net positive impact of internationalisation, with direct benefits counting from 2.4 to 3.1 times the costs and highlighting a net contribution of $€ 460-666$ per Flemish inhabitant. A similar study conducted in the USA by the Institute of International Education (2019) reported a net contribution of $\$ 41$ billion due to international students in 2018/2019. Despite the large value, this is equal to nearly $€ 116$ per inhabitant, which is lower than the estimated effect in Flanders.

Our findings confirm the relevance of international students, as their presence is associated with net benefits to the local economy. However, there are a number of considerations to be discussed. First, the favourable benefit-cost ratio is primarily driven by the long-term impact of international students on the local economy. We observe a high stay rate, equal to $52.8 \%$ of graduate international students. Bijwaard (2010) estimated a stay rate of $19 \%$ for students in the Netherlands, even though other studies reported a probability of stay ranging between 29 and $94 \%$ in the Netherlands, while the numbers vary between 3 and $64 \%$ for the UK (Weisser, 2016). Second, it can be noted that during studies costs exceed benefits, creating a net balance that is represented in Figure 2 (Year 0, when a net loss of nearly $€ 1240$ million is highlighted). We are aware of the fact that education expenditure is not a pure cost, as it contributes to the national stock of human capital and generates positive "soft" externalities. However, we need to limit our assumptions in order to make our model measurable. Despite this simplification, already one year after graduation benefits prevail, due to wage taxation. We see that the payback time for an international student amounts to nearly four years, which means that if students stay for four years or more after graduation, the costs for their education would be rebalanced by their contributions to the job market, especially in terms of wage taxation. This result is partially driven by the labour market conditions in Flanders, where the unemployment rate is relatively low (around 5\% on average, $8 \%$ one year after graduation as retrieved by the Social Security data) and the level of taxation is relatively high $(53.9 \%$ plus $32.8 \%$ of employer contribution). Third, the prevalence of net benefits persists along the entire time horizon as long as students work and live in the country, except for the last few years, in which costs for pensions outweigh the net benefits.

The study also contributes to the debate on the indirect impact of internationalisation, finding no peer effect due to the presence of international students at master and advanced master levels at the KU Leuven. The results may be due to the fact that the peer effect is not detectable as an impact on "hard" measures of educational attainment, like time to graduation or GPA, while the influence may be visible on "soft" aspects like classroom climate and engagement. As suggested by Inspectie van het Onderwijs (2019), international students might 


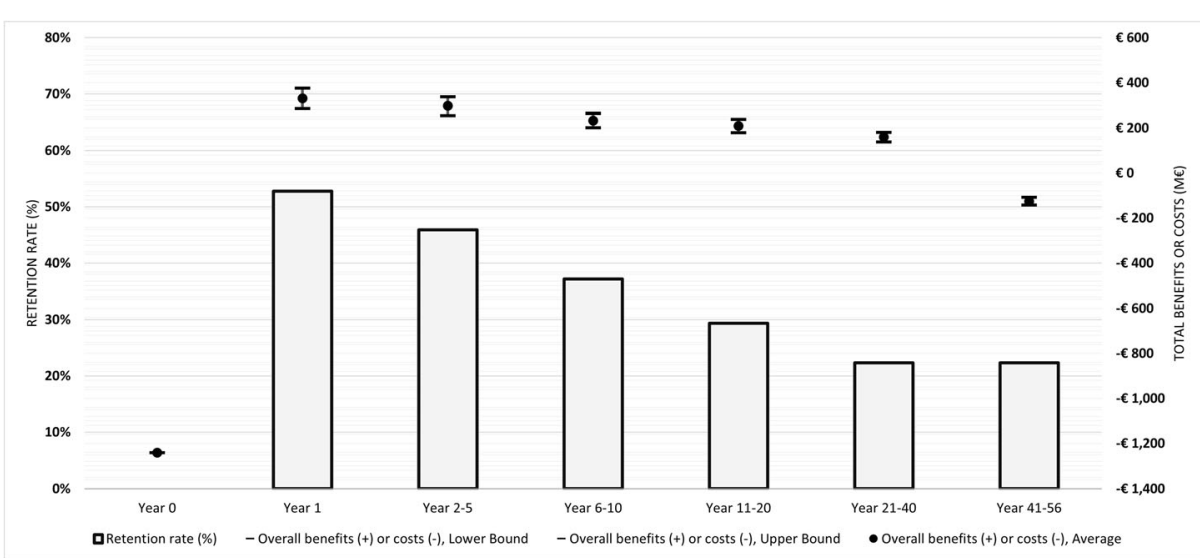

Figure 2 Students' stay rate and total benefits and costs of internationalisation over time. Note: Year 0: Year of student graduation. Years 1-56 refer to the years after student's graduation, considering an average graduating age of 25 and an average life expectancy of 81 (56 years after graduation). The left axis refers to the stay rate, defined as the probability that a graduate student continues to stay in Flanders after graduation (as such, it is computed since the first year after graduation, which is year 1) and it is represented by means of histograms. The right axis refers to the net total benefits (if greater than zero) or net total costs (if lower than zero) in each of the years represented in the time span, with lower and upper bounds of estimation. The reference line indicates the threshold between net benefits (upper part) and net costs (bottom part)

also be insufficiently integrated into the international classroom. Finally, it is worth stressing that this part of the analysis was applied to data from a single university and this may affect the generalisability of findings.

Within the frame of the growing debate about the costs and benefits of internationalisation in higher education, some policy implications are derived from this study. First, the process of internationalisation of higher education brings net benefits especially in combination with students' retention after graduation. Hence, policies aimed at stimulating international students' stay rates should be designed to maximise net benefits, in line with previous findings on the topic (Bergerhoff et al., 2013). Based on our results, net benefits outweigh the costs after more than four years from graduation. After ten years from graduation, the net benefits double the costs. From this perspective, policymakers should promote reforms aimed at student retention, for instance offering tax reduction to companies hiring international students. In addition, as pointed out by Han et al. (2015) and by Migration Advisory Committee (MAC) (2018), the debate about the ability to retain international students is closely linked to the availability of visas and permits to stay in the country, especially for extra-EU students. Second, competition in the job market could arise in hosting economies as well, between international and native graduates. As shown by Kahanec and Králiková (2011), "Skilled immigration benefits the low-skilled native labour force and may, but does not need to hurt high-skilled native workers" (p. 3). Indeed, high-skilled immigration is found to have a redistributive effect (Kahanec \& Zimmermann, 2008) beneficial for inequality reduction, but it may also put pressure on the competition for high-skilled job positions resulting in ambiguous effects. Additional considerations concern the presence of cost economies that would make internationalisation economically advantageous both marginally and on average (Zhang et al., 2017; Zhang \& Worthington, 2018), but also, in a wider context, the relevance of cultural-related effects in positively affecting internationalisation, despite these factors are generally difficult to measure (Kahanec \& Králiková, 2011; OECD, 2018a). Policymakers should inform the wider public on the relevance, importance and added value of internationalisation in higher education. 
Supplementary Information The online version contains supplementary material available at https://doi.org/ 10.1007/s10734-021-00737-0.

Acknowledgements We are grateful to the participants of the LEER conference on Education Economics, AEDE Meeting, seminar participants at KU Leuven, VARIO board members, the VLUHR steering committee, Sarah Van Steenkiste, Luc Sels and two anonymous referees for insightful comments. A policy report based on this paper has been published as De Witte, K., Soncin, M., Vansteenkiste, S., \& Sels, L. S. (2020). De economische effecten van internationalisering in het hoger onderwijs. Studie in opdracht van de "Vlaamse Universiteiten en Hogescholen Raad'(VLUHR) en de Vlaamse Adviesraad voor Innoveren en Ondernemen (VARIO).

Funding Open access funding provided by Politecnico di Milano within the CRUI-CARE Agreement. Kristof De Witte acknowledges financial support from the Flemish University Council (VLIR).

Open Access This article is licensed under a Creative Commons Attribution 4.0 International License, which permits use, sharing, adaptation, distribution and reproduction in any medium or format, as long as you give appropriate credit to the original author(s) and the source, provide a link to the Creative Commons licence, and indicate if changes were made. The images or other third party material in this article are included in the article's Creative Commons licence, unless indicated otherwise in a credit line to the material. If material is not included in the article's Creative Commons licence and your intended use is not permitted by statutory regulation or exceeds the permitted use, you will need to obtain permission directly from the copyright holder. To view a copy of this licence, visit http://creativecommons.org/licenses/by/4.0/.

\section{References}

Bergerhoff, J., Borghans, L., Seegers, P. K., \& Van Veen, T. (2013). International education and economic growth. IZA Journal of European Labor Studies, 2(1), 3.

Bijwaard, G. E. (2010). Immigrant migration dynamics model for The Netherlands. Journal of Population Economics, 23(4), 1213-1247.

Caruso, R., \& De Wit, H. (2015). Determinants of mobility of students in Europe: empirical evidence for the period 1998-2009. Journal of Studies in International Education, 19(3), 265-282.

CPB. (2012). De economische effecten van internationalisering in het hoger onderwijs. CPB Notitie. Retrieved from https://www.cpb.nl/publicaties.

Chishti, S. (1984). Economic costs and benefits of educating foreign students in the United States. Research in Higher Education, 21(4), 397-414.

De Villé, P., Martou, F., \& Vandenberghe, V. (1996). Cost-benefit analysis and regulatory issues of student mobility in the EU. European Journal of Education, 31(2), 205-222.

London Economics. (2018). The costs and benefits of international students by parliamentary constituency. Retrieved from https://www.hepi.ac.uk/category/publications/.

Felbermayr, G. J., \& Reczkowski, I. (2012). International student mobility and high-skilled migration: the evidence. Ifo Working Paper 132.

González, C. R., Mesanza, R. B., \& Mariel, P. (2011). The determinants of international student mobility flows: an empirical study on the Erasmus programme. Higher Education, 62(4), 413-430.

Han, X., Stocking, G., Gebbie, M. A., \& Appelbaum, R. P. (2015). Will they stay or will they go? International graduate students and their decisions to stay or leave the US upon graduation. PLoS One, 10(3), e0118183.

Kahanec, M., \& Králiková, R. (2011). Pulls of international student mobility. IZA Discussion paper n. 6233. Institute for the Study of Labor.

Kahanec, M., \& Zimmermann, K. F. (2008). Migration, the quality of the labour force and economic inequality. IZA Discussion Paper No. 3560. Institute for the Study of Labor.

Kim, D., Bankart, C. A., \& Isdell, L. (2011). International doctorates: trends analysis on their decision to stay in US. Higher Education, 62(2), 141-161.

Knight, J. (2013). The changing landscape of higher education internationalisation-for better or worse? Perspectives: policy and practice in highereducation, 17(3), 84-90.

Levin, H. M. (1987). Cost-benefit and cost-effectiveness analyses. New directions for program evaluation, 1987(34), 83-99.

Levin, H. M., McEwan, P. J., Belfield, C., Bowden, A. B., \& Shand, R. (2017). Economic evaluation in education: cost-effectiveness and benefit-cost analysis. SAGE publications. 
London \& Partners (2018). The economic impact of London's international students. Retrieved from https://files. londonandpartners.com/.

MAC. (2018). Impact of international students in the UK. Retrieved from https://assets.publishing.service.gov. $\mathrm{uk} /$.

Münch, C., \& Hoch, M. (2013). The financial impact of cross-border student mobility on the economy of the host country. Retrieved from https://eu.daad.de/.

Naidoo, V. (2007). Research on the flow of international students to UK universities: determinants and implications. Journal of Research in International Education, 6(3), 287-307.

OECD. (2013a). Database on Immigrants in OECD and non-OECD Countries: DIOC, 2010/11 Retrieved from http://www.oecd.org/els/mig/dioc.htm.

OECD. (2013b). Pensions at a Glance 2013, OECD and G20 Indicators. OECD Publishing.

OECD. (2018a). Education at a Glance 2018: OECD Indicators. OECD Publishing. https://doi.org/10.1787/eag2018-en.

OECD. (2018b). Country statistical profile: Belgium 2018/4, in Country statistical profiles: key tables from OECD. OECD Publishing. https://doi.org/10.1787/csp-bel-table-2018-4-en.

OECD. (2019a). Education at a Glance 2019: OECD Indicators. OECD Publishing.

OECD. (2019b). Social expenditure update 2019, Public social spending is high in many OECD countries. OECD Publishing.

Oosterbeek, H., \& Webbink, D. (2011). Does studying abroad induce a brain drain? Economica, 78(310), 347366.

Rumbley, L. (2012). So many data, so little clarity. In J. Beelen \& H. De Wit (Eds.), Internationalisation revisited: new dimensions in the internationalisation of higher education (pp. 125-134). CAREM.

Sacerdote, B. (2001). Peer effects with random assignment: results for Dartmouth roommates. The Quarterly Journal of Economics, 116(2), 681-704.

Schreyer, P., \& Koechlin, F. (2002). Purchasing power parities-measurement and uses. Statistics Brief, 3(2002/ 3), 1-8.

Thompson, G. (2009). Statistical literacy guide - how to adjust for inflation. House of Commons Library.

Throsby, C. D. (1991). The financial impact of foreign student enrolments. Higher Education, 21(3), 351-358.

Throsby, D. (1998). Financing and effects of internationalisation in higher education. In The economic costs and benefits of international student flows. OECD-CERI.

van het Onderwijs, I. (2019). Internationalisering en de toegankelijkheid van het hoger onderwijs voor Nederlandse studenten $\mathrm{pp}$. 70.

Van Mol, C., \& Timmerman, C. (2014). Should I stay or should I go? An analysis of the determinants of intraEuropean student mobility. Population, Space and Place, 20(5), 465-479.

Van Mol, C., Caarls, K., \& Souto-Otero, M. (2020). International student mobility and labour market outcomes: an investigation of the role of level of study, type of mobility, and international prestige hierarchies. Higher Education, 1-27.

VARIO. (2017). Internationaal Toptalent Aantrekken En Verankeren. Advies Nr, 1 Retrieved from https://www. vlaanderen.be/nl/publicaties.

Toerisme Vlaanderen (2017). Tourism in key figures edution 2017. Retrieved from https:/www.vlaanderen.be/ $\mathrm{nl} /$ publicaties/.

Toerisme Vlaanderen (2018). Art cities research 2018. Retrieved from https://www.vlaanderen.be/nl/publicaties/.

Weisser, R. (2016). Internationally mobile students and their post-graduation migratory: an analysis of determinants of student mobility and retention rates in the EU. In OECD Social, Employment and Migration Working Papers, No. 186. OECD Publishing.

Wiers-Jenssen, J. (2008). Does higher education attained abroad lead to international jobs? Journal of Studies in International Education, 12(2), 101-130.

Zhang, L. -C., \& Worthington, A. C. (2018). Explaining estimated economies of scale and scope in higher education: a meta-regression analysis. Research in Higher Education, 59(2), 156-173.

Zhang, L. C., Worthington, A. C., \& Hu, M. (2017). Cost economies in the provision of higher education for international students: Australian evidence. Higher Education, 74(4), 717-734.

Zimmerman, D. J. (2003). Peer effects in academic outcomes: evidence from a natural experiment. Review of Economics and Statistics, 85(1), 9-23.

Publisher's note Springer Nature remains neutral with regard to jurisdictional claims in published maps and institutional affiliations. 